\title{
Dariusz Kotecki, Zrozumieć Apokalipsę? Szkice egzegetyczno- -teologiczne (Biblioteka Szkoły DABAR 1; Rzeszów: Bonus Liber 2021). Ss. 294. 21 PLN. ISBN 978-83-66566-78-1
}

\section{PAWE PODESZWA}

Uniwersytet im. Adama Mickiewicza w Poznaniu podpaw@amu.edu.pl, ORCID: 0000-0002-4000-1660

Doświadczenia naukowe, dydaktyczne oraz duszpasterskie jednoznacznie wskazują, że ostatnia Księga Nowego Testamentu - Apokalipsa św. Jana - cieszy się coraz większym zainteresowaniem nie tylko biblistów i teologów, ale także wiernych, szukających w niej umocnienia wiary oraz orędzia nadziei i pocieszenia. Może to wydawać się nieco zaskakujące, biorąc pod uwagę specyfikę literacką i teologiczną Apokalipsy oraz wynikające z niej trudności interpretacyjne, zwłaszcza związane z wszechobecnym i wieloaspektowym symbolizmem Księgi. Trafnie wyraził to kard. Gianfranco Ravasi, pisząc, że „symbolizm jest jakby płaszczem, który rozciąga się nad wszystkimi stronnicami Apokalipsy" (Apokalipsa, [Kielce: Jedność 2002] 9). Na uznanie zasługują zatem wszelkie wysiłki komentatorów Apokalipsy, zmierzające do rzetelnego wyjaśnienia tekstu biblijnego poprzez „odsłanianie symbolu”. Pozwala to dotrzeć do przesłania teologicznego Księgi, a także wydobyć rozmaite prawdy egzystencjalne, mające istotne znaczenie dla współczesnych wyznawców Jezusa.

$Z$ dużym zainteresowaniem przeczytałem opracowanie ks. Dariusza Koteckiego, Zrozumieć Apokalipsę? Szkice egzegetyczno-teologiczne, które ukazało się w ramach nowej serii wydawniczej: Biblioteka Szkoły DABAR. Stanowi ono bardzo dojrzałą refleksję nad przesłaniem ostatniej księgi Biblii. W wielu wcześniejszych publikacjach (monografiach i licznych artykułach) autor dał się już poznać jako doskonały znawca Apokalipsy. Jak sam przyznaje, recenzowana publikacja jest „rodzajem syntezy moich dotychczasowych analiz tej księgi (dlatego czytelnik nie znajdzie w niej licznych odnośników bibliograficznych, które znajdują się w moich uprzednich opracowaniach), przygotowanej w taki sposób, aby zobaczyć w Apokalipsie przesłanie nadziei i zwycięstwa w czasach «gasnącej nadziei» $\mathrm{i}$ «przegranej» - chociaż tylko pozornej - chrześcijaństwa” (s. 23). Podtytuł jasno wskazuje, że „niniejsza publikacja nie jest komentarzem biblijnym w klasycznym rozumieniu, tj. takim, w którym po części wstępnej, proponującej rozwiązania dotyczące problematyki wchodzącej w zakres krytyki historycznej (autor, czas powstania, adresaci etc.), zagadnień literackich (struktura dzieła, język, styl, gatunek literacki etc.) umieszcza się szczegółowy 
komentarz historyczno-krytyczny, filologiczny do poszczególnych zdań, wyrazów, aby potem zaproponować jakąś wizję teologiczną komentowanego ustępu” (s. 22). Są to natomiast szkice egzegetyczno-teologiczne, które mają "pomóc czytelnikowi w uchwyceniu całego przesłania Apokalipsy" (s. 23). Trzeba od razu zauważyć, że autorowi udało się zrealizować wyznaczony sobie cel. Zaproponowane szkice nie tylko przyczynią się do lepszego zrozumienia samego tekstu wraz z jego rozbudowanym symbolizmem, choć to zawsze jest koniecznym punktem wyjścia do poprawnych wniosków teologicznych i egzystencjalnych, ale dają możliwość czytelnikowi „poczuć jej klimat, stać się cząstką tego doświadczenia apokaliptycznego, w którym przewodnikiem był Jan z Patmos" (s. 231). Dariusz Kotecki ma całkowitą rację, że „do tej księgi trzeba sięgać nieustannie, aby zrozumieć własną historię i dzieje świata, te przeszłe, teraźniejsze i przyszłe, i patrzeć na nie z perspektywy Boga, Pana historii, «Który jest i Który był, i Który przychodzi» (Ap 1,4). Apokalipsa wydarza się naprawdę i może tego doświadczyć tylko ten, «kto ma ucho»" (s. 272).

Recenzowana publikacja składa się z przedmowy autorstwa ks. Adama Kubisia, wprowadzenia, dziesięciu rozdziałów (pierwszy ma charakter introdukcyjny, a pozostałe dziewięć zawiera szkice egzegetyczno-teologiczne do poszczególnych części Apokalipsy), bibliografii oraz indeksu autorów.

We wprowadzeniu znajdujemy wiele ciekawych informacji odnoszących się do potocznego rozumienia Apokalipsy, zwłaszcza opisanych tam kataklizmów, oraz zagadek i tajemnic, przed którymi staje czytelnik Księgi. Autor od samego początku słusznie zwraca uwagę, że Apokalipsa jest zaproszeniem do odkrywania głębszego sensu Paschy Jezusa oraz niesie orędzie nadziei i pocieszenia na trudne czasy Kościoła. Jednocześnie staje się wezwaniem do nieustannego nawracania się i zawiera rozmaite przestrogi oraz ostrzeżenia. Autor porusza także kwestie historii interpretacji Księgi, oscylujące między dosłownością i alegorią. Pisze również o modelach interpretacyjnych (symboliczny lub duchowo-idealistyczny; historyzujący; futurystyczny; preterystyczny; paschalny), które starają się uwypuklić obecną w Apokalipsie teologię historii. Syntetycznie omawia także kwestię oddziaływania tekstu (Wirkungsgeschichte) wraz z konkretnymi przykładami inspirującego wpływu Apokalipsy na kulturę.

Pierwszy rozdział, „Zanim zaczniesz czytać Apokalipsę”, przybliża czytelnikowi podstawowe zagadnienia związane $\mathrm{z}$ analizowaną Księgą. Ich znajomość jest konieczna i pożyteczna dla lepszego jej zrozumienia. Najpierw zostały wskazane kryteria oraz klucze hermeneutyczne, pomagające właściwie odczytać Apokalipsę. Lata badań nad tą Księgą pozwoliły autorowi sformułować kilka cennych wskazań, które należy uwzględnić przy interpretacji Apokalipsy: 1) kontekst liturgiczny Księgi; 2) Apokalipsa jako Księga formująca mentalność wspólnoty przez medytację Pism Starego Testamentu w kluczu chrystologicznym; 3) gatunek literacki; 4) symbolizm jako naturalne narzędzie komunikacji; 5) konieczność uwzględnienia środowiska, w którym żyje wspólnota (zarówno uwarunkowania wewnętrzne i zewnętrzne); 6) funda- 
ment teologiczny Apokalipsy, to jest proklamacja prawdziwego obrazu Boga działającego w historii świata.

Pod koniec wprowadzenia autor omawia literacką strukturę Księgi (prolog Ap 1,1-8; dwie zasadnicze części: epistolarna Ap 1,9-3,22 oraz mówiąca o planie i działaniu Boga w historii Ap 4,1-22,5; epilog Ap 22,6-21). Ksiądz Kotecki zauważa także, że „czytając Apokalipsę nie można zapomnieć, że jest to tekst narracyjny, opowiadanie [...]. Narrator w Apokalipsie utożsamia się z Janem, który przebywając na wyspie Patmos, doświadcza czegoś niezwykłego [...] czym chce się podzielić ze swoimi siostrami i braćmi w wierze. Jest to dzielenie się swoim doświadczeniem. Przekazując im to swoje doświadczenie, zaprasza ich w tę samą podróż, która w zetknięciu $z$ ich doświadczeniem, zarówno wspólnotowym, jak i indywidualnym, staje się tą samą podróżą, ale wcale nie taką samą. Komentując Apokalipsę według zaproponowanej struktury, będziemy mieli możność uchwycenia jej nici narracyjnej i głębszego zrozumienia jej przesłania, i tym samym wejścia w doświadczenie Jana z Patmos" (s. 62-64).

Kolejne dziewięć rozdziałów to szkice egzegetyczno-teologiczne do poszczególnych części Apokalipsy, które zgodnie z przyjętym założeniem, proponują czytelnikowi swoistego rodzaju podróż, pozwalającą wejść w doświadczenie wizjonera z Patmos. Przyjęty przez autora podział tekstu respektuje strukturę literacką samej Księgi i daje możliwość dostrzeżenia „jej nici narracyjnej” (s. 64): „Początek «Objawienia Jezusa Chrystusa» (Ap 1,1-8)"; „Spotkanie ze Zmartwychwstałym (Ap 1,9-20)”; „Zmartwychwstały mówi do Kościołów (Ap 2,1-3,22)”; „Bóg, Baranek i Duch Święty - Pan dziejów (Ap 4,1-5,14)”; „Baranek otwiera siedem pieczęci (Ap 6,1-8,5)”; „Aktywna bliskość Boga w historii (Ap 8,6-11,19)”; „Kościół, antyboska trójca i idolatria Bestii (Ap 12,1-16,21)”; „Ostateczne osądy Boga (Ap 17,1-22,5)”; „ «Tak, przyjdę wkrótce» (Ap 22,20). Epilog Księgi Apokalipsy św. Jana (22,6-21) i epilog książki”.

Każdy rozdział zawiera najpierw przekład tekstu biblijnego. Jak informuje sam autor, w publikacji korzysta z tłumaczenia, „które po raz pierwszy zostało wydane w ramach albumu towarzyszącego wystawie prac Artura Majki w Muzeum Archidiecezji Warszawskiej: Apokalipsa Świętego Jana (tłum. i kom. D. Kotecki; ilustracje A. Majka) (Warszawa: Muzeum Archidiecezji Warszawskiej - Paris: Galerie Roi Doré 2019)" (s. 23). W zaproponowanym tutaj przekładzie, bazującym na tekście z krytycznego wydania Nowego Testamentu: Aland-Nestle, Novum Testamentum Graece et Latine, wyd. 28 (2012), zostały wprowadzone niewielkie korekty. W ten sposób zyskujemy nowy i rzetelny przekład tekstu Apokalipsy. Ponadto w samym tekście biblijnym znalazły się też liczne odnośniki do innych fragmentów, zarówno z Apokalipsy, jak i pozostałych ksiąg biblijnych, których porównanie ułatwia rozumienie poszczególnych terminów i pojęć, a także daje możliwość lektury i medytacji metodą skrutacji, zgodnie ze znaną zasadą, że Pismo Święte wyjaśnia samo siebie.

Każdy analizowany fragment Apokalipsy osadzony został najpierw w strukturze Księgi, aby następnie przejść do jego wyjaśnienia egzegetyczno-teologicznego. 
Omówienie siedmiu Listów do Kościołów Apokalipsy (Ap 2,1-3,22) zostało poprzedzone syntetycznym „wprowadzeniem ogólnym”, w którym autor wyjaśnia ich strukturę literacką (sześć charakterystycznych części: 1) adres; 2) autoprezentacja; 3) osąd Chrystusa nad Kościołem; 4) wezwanie szczegółowe; 5) obietnica dla zwycięzcy; 6) wezwanie ogólne) oraz zwraca uwagę na obecność i znaczenie stałych elementów występujących we wszystkich listach. Autor słusznie akcentuje, że ich schemat jest dialogiczny, pokutny i zarazem programowy. Wszystkie te aspekty odnajdziemy w zaproponowanej dalej analizie egzegetyczno-teologicznej poszczególnych listów do lokalnych wspólnot kościelnych Azji Prokonsularnej, które ostatecznie są skierowane do Kościoła wszystkich czasów, zgodnie z wezwaniem ogólnym, powracającym siedmiokrotnie „kto ma ucho niechaj posłyszy, co mówi Duch do Kościołów” (Ap 2,7.11.17.29; 3,6.13.22).

W prowadzonych analizach egzegetycznych ks. Kotecki wybiera podejście synchroniczne, poddając najważniejsze elementy, niezbędne do poprawnego rozumienia tekstu biblijnego, analizie typu literackiego. Polega ona na szukaniu sensu poszczególnych wyrazów, wyrażeń, formuł, całych obrazów w oparciu o paralele biblijne i pozabiblijne, bliższy i dalszy ich kontekst w ramach Księgi. Ten sposób wyjaśnienia tekstów pozwala mu dotrzeć do przesłania Apokalipsy oraz wydobyć istotne elementy jej teologii, które jednocześnie mają dla chrześcijan ważne znaczenie egzystencjalne.

Na uznanie zasługuje fakt, że autor nie tylko respektuje wcześniej podane i omówione kryteria interpretacji Apokalipsy, ale udaje mu się przekonać czytelnika, że chrystocentryzm teologiczny stanowi fundamentalny temat Apokalipsy. Właśnie od jego odkrycia oraz uchwycenia jego specyficznej dynamiki zależy w dużej mierze poprawne odczytanie przesłania Apokalipsy jako Księgi pocieszenia. Zaproponowane wyjaśnienia i interpretacje jasno ukazują, że jedynym Panem historii jest Bóg. Wszedł On nieodwracalnie i nieodwołalnie w historię świata przez swojego Syna Jezusa Chrystusa. To w Nim ofiarował światu zbawienie. Jezus to Baranek „stojący, jakby zabity" (Ap 5,6), którego zwycięstwo dokonało się w misterium paschalnym. Jest ono ostateczne, chociaż jego skutków do końca jeszcze nie widać. Chrześcijanie zwyciężają wszelkie zło tylko i wyłącznie dzięki mocy, która płynie z paschalnego misterium Jezusa (Ap 7,14; 12,11). Autor opracowania słusznie zauważa, że dwie zasadnicze części Apokalipsy otwierają wizje: Ap 1,9-20 i Ap 4-5, przekazujące „słuchaczom nic innego jak teologiczny fundament zrozumienia rzeczywistości, w której żyją chrześcijanie. Żadna rzeczywistość nie wyrywa się spod panowania Boga i Baranka (Jezusa Zmartwychwstałego), stąd może w Apokalipsie tak liczne - jak w żadnej innej księdze Nowego Testamentu - nagromadzenie czasowników w formie strony biernej, którą możemy zinterpretować jako passivum theologicum lub divinum, tzn. taką formę, w której podmiotem czynności jest sam Bóg. Jest to szczególnie zaskakujące w tych miejscach Apokalipsy, gdzie opisywane są najróżniejsze plagi, kataklizmy, pojawienie się szatańskich istot [...]. Nie mamy wątpliwości, że 
dotykamy w Apokalipsie tajemnicy Bożej Opatrzności, która jest nie tylko wiedzą Boga o przyszłych losach świata i każdego z nas, ale oznacza Jego moc, która kieruje światem i jemu przewodzi” (s. 59-60).

Warto również podkreślić, że zaproponowane szkice zawierają także istotną aktualizację przesłania Apokalipsy. To jest bardzo ważne z punktu widzenia współczesnego czytelnika, ponieważ dla wielu ostatnia Księga Nowego Testamentu pozostaje tekstem „tajemnym” i jakby „,dalekim” od rzeczywistości życia ludzkiego. Jest niemal jak drogocenna perła, która leży na dnie głębokiego oceanu, czekając na człowieka, który ją znajdzie, a następnie wydobędzie, i dzięki temu będzie mogła zachwycić wielu swoim pięknem i głębią teologicznego przesłania. Wydaje mi się, że recenzowana publikacja ks. Koteckiego jest niezwykle znaczącym przyczynkiem do owego wydobywania jakże pełnego nadziei orędzia Apokalipsy, że cała historia (bez żadnego wyjątku) przesiąknięta jest obecnością Chrystusa. Dotyczy to zarówno przeszłości, teraźniejszości, jak i przyszłości. Zatem przesłanie to jest aktualne i istotne dla każdego pokolenia chrześcijan, zwłaszcza tych, których codzienna egzystencja naznaczona została doświadczeniami pozornie przeczącymi tej fundamentalnej prawdzie chrześcijańskiej wiary. Sposób komentowania Apokalipsy przez autora publikacji pozwala czytelnikowi zrozumieć, że „Bóg w Apokalipsie to nie jest bóg deistów, ale Bóg żywy, Bóg wiary biblijnej, Bóg, który niepokoi, może wyprowadza z komfortu pozornej równowagi i stawia wymagania. Tylko uwzględniając wyżej wymienioną przesłankę teologiczną, która w Apokalipsie staje się jednocześnie chrystologiczną (jest to przykład teocentryzmu chrystologicznego), można uniknąć w lekturze tej księgi niebezpieczeństwa «hermeneutyki zlaicyzowanej», pozwalającej patrzeć na tekst biblijny tylko i wyłącznie jako na tekst z przeszłości, który należy badać jak każdy inny tekst starożytny, odróżniając źródła, określając formy czy zabiegi literackie, zapominając przy tym o występowaniu pierwiastka Bożego w ludzkich dziejach” (s. 60-61).

Jestem głęboko przekonany, że nowa książka ks. Dariusza Koteckiego będzie bardzo użyteczna i pomocna dla wszystkich wiernych, którzy w słowie Bożym dostrzegają istotny element ich wędrówki duchowej. Myślę, że niniejsza publikacja zostanie przyjęta bardzo życzliwie przez czytelników, zwłaszcza zainteresowanych orędziem zbawczym Apokalipsy, i bez wątpienia będzie stanowić kolejną cenną pomoc we wspólnotowej i samodzielnej lekturze medytacyjnej Księgi zamykającej kanon Nowego Testamentu. Tym samym uzyskujemy także nowe narzędzie tak ważnego i promowanego dzisiaj w Kościele apostolatu biblijnego (zob. Benedykt XVI, Verbum Domini, 75), zgodnie z zaleceniem Soboru Watykańskiego, aby wierni mieli szeroki dostęp do Pisma Świętego (zob. KO 22). Jednocześnie recenzowana publikacja jest kolejnym wymownym potwierdzeniem, że jej autor należy do grona najwybitniejszych współczesnych znawców problematyki Apokalipsy. 
